\title{
Cameroon's Environmental Impact Assessment Decree and Public Participation in Concession-Based Forestry: An Exploratory Assessment of Eight Forest-Dependent Communities
}

\author{
Dieudonne Alemagi ${ }^{1}$, Reem Hajjar ${ }^{2}$, Zac Tchoundjeu $^{1} \&$ Robert Kozak $^{2}$ \\ ${ }^{1}$ World Agroforestry Centre, Regional Office for West and Central Africa, Yaoundé, Cameroon \\ ${ }^{2}$ Faculty of Forestry, University of British Columbia, Vancouver, BC, Canada \\ Correspondence: Dieudonne Alemagi, World Agroforestry Centre, Regional Office for West and Central Africa, \\ P.O. Box 16317, Yaoundé, Cameroon. E-mail: D.Alemagi@cgiar.org
}

Received: April 12, $2013 \quad$ Accepted: September 3, $2013 \quad$ Online Published: September 11, 2013
doi:10.5539/jsd.v6n10p8

\begin{abstract}
This paper examines the degree to which public participation in concession-based forestry decision-making - as outlined by the Environmental Impact Assessment (EIA) Decree (No. 2005/0577/PM)-is taking place in eight forest-dependent communities of Cameroon. Of the total respondents that took part in the survey, only 39 per cent stated that they were involved in decisions concerning concession-based forestry. Furthermore, there seems to be a generally negative perception on the part of local communities towards the government's implementation of public participation legislation in concession-based forestry decision-making. Obstacles to public decision-making process are identified and recommendations are proffered for more effective public participation.
\end{abstract}

Keywords: public participation, forest management, Cameroon, forest-dependent communities

\section{Introduction}

Public participation is increasingly being incorporated into forest management decision-making around the world, the underlying reason being that effective public participation is essential to making decisions about sustainable forest management that result in successful outcomes (Buchy \& Hoverman, 2000; Mendoza \& Prabhu, 2000; Diaw et al., 2009). The UN Food and Agriculture Organization (2012) defines participatory forestry as "processes and mechanisms which enable people with a direct stake in forest resources to be part of decision-making in all aspects of forest management, including policy formulation processes." Public participation promotes a bottom-up approach to forest management, in general, and plays an important role in ensuring that the socio-economic, ecological, and cultural values of the public are fully considered in decision-making processes related to forest use and management (Bombay, 1996; Shindler \& Neburka, 1997; Duinker,1998; Buchy \& Hoverman, 2000; Pretty \& Smith, 2004). As participatory forest management has been regarded as a fundamental tool for achieving sustainable forest management (UNCSD, 1992; Montreal Process Working Group, 1999; WCFSD, 1999; Kozak et al., 2008), the legislation and policy frameworks of many forested jurisdictions around the world now contain provisions for public input on forest management issues (Duinker, 1998; Sinclair \& Doelle, 2003; Buchy \& Hoverman, 2000; Coskun \& Elvan, 2003; Alemagi et al., 2007).

\section{Government Efforts to Promote Participatory Forest Management in Cameroon}

In Cameroon, for example, the government has created several legal and policy initiatives in an attempt to create a more participatory forest sector. Community forest tenures, officially endorsed in 1994 as part of the country's major forestry law (Law N0. 94/01 of 20th January 1994), were created partly for this reason. This law and its Decree of implementation (Decree N0. 95-531-PM of 23rd August 1995) aimed to increase the participation of local populations in sustainable forest management, thereby increasing their living standards and protecting the ecological integrity of the forest in which they reside (MINFOF, 2009). This legislation has led to 147 community forest tenures being created since 1994, covering more than 621,245 hectares (Kongape \& Etoa-Akoa, 2011). The 1994 Forestry Law and its Decree of application also transfer ownership rights of some forests to local municipalities (referred to as council forests). This includes any forest that is planted by a 
municipality on land belonging to that municipality or any forest which is classified and assigned to a municipality (ROC, 1994).

Another form of participatory forest management in Cameroon manifests itself through the so-called "model forest" approach. In August 2005, the government of Cameroon created two model forests: the Campo Ma'an and $\mathrm{Dja}$ et Mpomo (estimated at 1.5 million hectares) in the South and East regions of country, respectively (CIFOR, 2006). The basic premise here is that all actors that have an interest in a particular forest, including traditional chiefs, indigenous communities, industries, governments, research institutes, and civil society, come together to contribute ideas and share experiences that can be used to manage a forest in a sustainable and equitable manner (Jum et al., 2007). However, despite these efforts to promote participatory forest management, concession-based forestry continues to play the most significant role in Cameroon's forestry sector.

\section{An Overview of Concession-Based Forestry in Cameroon}

Concession-based forestry is defined as the provision of forest tenures to large-scale timber companies for the purpose of harvesting timber (Karsenty, 2007; Alemagi \& Kozak, 2010). These tenures encompass about $67 \%$ of the country's production forests and the concessionaires that operate on them provide employment to about 25,000 individuals (Karsenty, 2007). As the sixth largest exporter of tropical woods in the world (Nguemdjom, 2006), the industrial forestry sector makes a sizable contribution to Cameroon's total export base, with timber-based forest products accounting for 18.9 billion (Note 1) CFA Franc in 2008 (OFAC, 2012).

Unfortunately, this export-oriented model of forest exploitation has also had detrimental social impacts for the communities that host forest products firms. Most of these companies operating within the 114 concessions in Cameroon (as of May 2011; Lescuyer et al., 2012) are foreign-owned and operate on large tracts of land up to 200,000 hectares in size (MINEF, 1994), but 75,000 hectares, on average (Karsenty, 2007). Generally, concessions overlap with other land uses, including village forests used by local communities for a number of purposes. These companies can and do generate immense wealth for corporations and government coffers (Oyono et al., 2005; Njoh, 2007). However, very little of it finds its way back to the communities in which they operate (The Rainforest Foundation \& Forests Monitor, 2007) and extreme poverty conditions persist in most forest-dependent communities in and around these concessions (Friends of the Earth International, 2005; The Rainforest Foundation \& Forests Monitor, 2007).

Given the dominance of concession-based forestry in Cameroon, and elsewhere in Central and Western Africa (Karsenty, 2007), it is of vital importance to consider public participation as an effective means of promoting sustainable forest management. In Cameroon, public participation and the associated provision of local benefits to communities under concessionaires is prescribed in various forms of legislation, outlined below.

First, forest concession contracts must include a cahiers de charges specifying, inter alia, obligations of the concessionaires towards contributing to social and economic development of the areas covered by their concessions. These are meant to be negotiated with local administrative authorities and sometimes the affected communities (Karsenty, 2007; Global Witness, 2010), giving a voice to local populations. In addition, during elaboration of forest management plans, agreements are to be reached between forest products companies and affected communities regarding social infrastructure construction, such as schools or health care buildings. These obligations, however, are often not met (Global Witness, 2010), and companies have been criticized for poor quality of construction (Karsenty et al., 2008).

Legislation has also been enacted (Order No. 0520/MINATP/MINFI/MINFOF of 2010) stipulating that forest royalties paid by concessionaires are to be distributed, in part, to affected local populations. Specifically, 50 per cent of Annual Forest Fees go into the national treasury, 20 per cent to councils that cover the jurisdiction where the forest operation is located, 20 per cent to FEICOM (Fonds Spécial d'Equipement et d'Intervention Intercommunale-a government institution that provides support to municipal councils) for distribution to other municipalities in the country, and 10 per cent to the communities within which the forest operation is situated.

A third, less examined piece of legislation applicable to public participation in concession-based forestry is the Environmental Impact Assessment (EIA) Decree (No. 2005/0577/PM). Enacted in 2005, the Decree lays down the process and the procedural framework governing EIA for any development project that has the potential to inflict harm on the environment, making it applicable to forestry activities. In the context of forestry, the Decree states that the concession holder must ensure that public consultations and meetings are organized to sample the opinions of the population at large on the project. This includes advertising the EIA for the development project, recording possible opposition to the project, and providing a forum for affected populations to discuss the findings of the EIA. While the Decree has been cited as a positive step towards incorporating public participation in concession-based forestry (Alemagi et al., 2007), it has been noted in other sectors-most notably large-scale 
energy infrastructure projects-that public involvement was lacking in practice despite the presence of a legal framework (Nguene et al., 2012; Bitondo, 2000). An additional issue relates to the fact that the Decree does not require that consultation occurs during the early phases of project development (Foti \& Silva, 2010), nor does it explicitly state that the opinions of the population at large will actually be accounted for in project plans.

Against this backdrop, we argue that an empirical study of the EIA's participation procedures in concession-based forestry is warranted and would make a significant contribution to the literature on participatory decision-making for sustainable forest management in Cameroon and perhaps elsewhere. While several studies have been undertaken to examine public participation in community and council forest tenures (see, for example, Oyono, 2004; Oyono, 2005; Assembe Mvondo \& Sangkwa, 2009; Brown \& Lassoie, 2010; De Blas et al., 2011); biodiversity conservation and management initiatives (Nguinguiri, 1999; Jum \& Oyono, 2005; Nchotaji, 2010), and even for benefit distribution and social development within concessions (see, for example, Bigombé Logo, 1994; Oyono et al., 2005; Oyono, 2005; Karsenty, 2007; Morrison, 2009; Foti \& Silva, 2010; Cerutti et al., 2010), the implementation of participation provisions of the EIA Decree in concession-based forestry has not yet been studied (Note 2). In this paper, we examine public perceptions (Note 3) of public participation and decision-making - as outlined by the EIA Decree - in eight forest-dependent communities impacted by concession-based forestry in the Southwest Region of Cameroon. Based on the results of this analysis, we offer recommendations for promoting participatory concession-based forestry in these communities. The specific objectives of this study are threefold:

(1) To ascertain the extent to which the public in eight forest-dependent communities of the Southwest Region of Cameroon perceive themselves to be engaged in the decision-making process regarding concession-based forestry, as outlined by the EIA Decree;

(2) To assess public opinions on the role of the government in promoting public participation in concession-based forestry in these forest-dependent communities; and

(3) To identify public perceptions of the major hurdles affecting public participation in these forest-dependent communities and to suggest policy recommendations for overcoming these obstacles.

It is hoped that the findings of this research will be incorporated into the dialogue on how to make concession-based forestry more participatory and, consequently, beneficial to local forest-dependent populations in Cameroon.

\section{Methods}

\subsection{Case Study Communities}

The communities under investigation comprised eight villages in the Eyumojock and Mamfe subdivision (Figure 1), a highly forest-dependent area in the Southwest Region of Cameroon: Kembong, Ewelle I and II (Note 4), Ajayukndip, Ossing, Talangaye, Okoroba, Mbinda-Taboh, and Bakogo. These particular forest-dependent communities were selected as representative of typical communities in the region, in terms of the following considerations. First, the communities are located close to many high value commercial tree species like Moabi (Baillonella toxisperma), Iroko (Milicia excelsa), and Azobé (Lophira slata). Second, while two large-scale forest products companies owned and controlled logging concessions in the communities, neither of them operated sawmills in the communities, and therefore, provided little in the way of local employment. Rather, logs harvested from these tracts of land were transported to larger urban centres (like Douala) where they were processed and likely exported. Finally, like most rural areas where 87 per cent of Cameroon's poor live (World Bank, 2011), acute poverty is endemic in each of the case study communities, as is a general lack of services. All of the communities lack good roads. Mbinda-Taboh and Bakogo do not have electricity. Healthcare services, including hospitals, health centres, and infirmaries, do not exist in Ewelle I and II, Okoroba, Mbinda-Taboh, and Talangaye. 


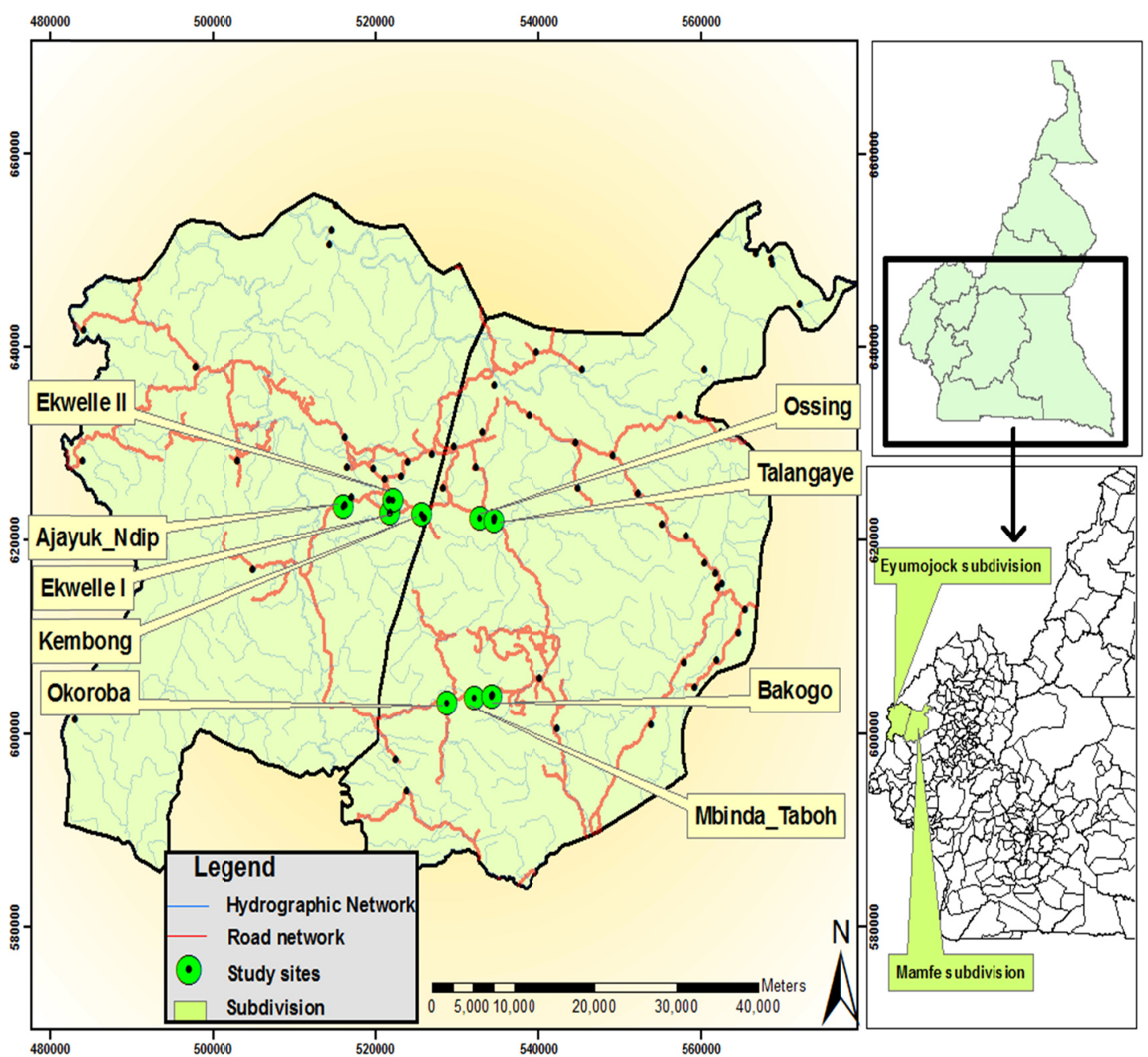

Figure 1. Case study area of Eyumojock and Mamfe subdivision, located in the southwest region of Cameroon

\subsection{Sample Selection}

Structured interviews were conducted with community respondents during June and July 2012 (using the survey instrument described below). A convenience sample (Note 5) of 507 adult individuals from all of the communities was recruited for the interviews (Table 1). As respondents approached the researchers for inclusion in the study, this sample was non-random (Note 6). As a result, we cannot exclude the possibility of non-response bias in this study. However, the large and representative sample size in this study likely means that non-response has been minimized (Israel, 2012). Moreover, given that this study is the first of its kind in the region, it is considered to be exploratory in nature and results should be interpreted accordingly. Two research assistants were recruited and trained to administer the questionnaires and help in conducting the interviews in all the communities. While a few of the respondents could read and completed the questionnaire on their own, most of the respondents were illiterate and interviews were conducted to assist them in completion of the questionnaire. Respondents were recruited from a cross-section of the population, including employees of the forest sector (Note 7), representatives from civil society, state officials, traditional chiefs, and other local residents. 
Table 1. Estimated population*, numbers of interviewees, and proportion of interviewees in each of the case study communities

\begin{tabular}{ccccc}
\hline Community & \multicolumn{2}{c}{ Population } & Interviewees & Proportion of interviewees (\%) \\
& $\begin{array}{c}2012 \text { Total } \\
\text { Estimate }\end{array}$ & $\begin{array}{c}\text { 2012 Adult } \\
\text { Estimate }\end{array}$ & & \\
\hline Kembong & 2000 & 800 & 151 & 19 \\
Ewelle I and II & 350 & 100 & 67 & 67 \\
Ajayukndip & 350 & 100 & 60 & 60 \\
Ossing & 1000 & 300 & 100 & 33 \\
Talangaye & 300 & 100 & 33 & 33 \\
Okoroba & 100 & 70 & 32 & 28 \\
Mbinda-Taboh & 70 & 40 & 11 & 76 \\
Bakogo & 200 & 70 & 53 & 32 \\
Total & $\mathbf{4 3 7 0}$ & $\mathbf{1 5 8 0}$ & $\mathbf{5 0 7}$ & \\
\hline
\end{tabular}

* Population estimates from each community were obtained from acting Chiefs and Heads of Traditional Councils.

Interviews were conducted at homes and offices either in English, Pidgin English, or the local dialect (Ijakgam) and each interview lasted approximately one hour, on average. To minimize the occurrence of biased responses, interviewers avoided leading the interviewees during the interviews (Kvale, 1996; Ammenberg, 2003) and reacted in a neutral manner by not signalling preferred answers (Ammenberg, 2003).

\subsection{Survey Instrument}

A questionnaire consisting of both open-ended questions and discrete categorical scales was designed for the purposes of this study. Ten questions were posed to community members. First, respondents were asked to state the name of their villages, occupations, and identify any relevant affiliations within the community (for example, government, traditional groups, religious groups, labour unions, forest-related corporate sector, or educational institutions).

Respondents were then asked more focused questions about their involvement in forest management decision-making. Specifically, they were asked whether they had been involved in such a process, and if so, to provide further details regarding their engagement in various aspects of the process (for example, supporting or opposing projects or programs of participation), the name(s) of the project(s), and their perceived levels of contribution to the process (using a 5-point continuous scale). This was followed by a question on their awareness of the EIA Decree (Decree N0. 2005/0577/PM) containing provisions for public participation in any developmental project likely to affect their forests, as well as their perceptions of the efficacy of the government in promoting and implementing this Decree (again, using a 5-point continuous scale). Finally, the last questions asked respondents to rank a series of potential obstacles to effective public participation in forest management decision-making, and to state any other comments that they had regarding public participation in forest management decision-making in their community. A similar line of questioning was used in a previous study on the constraints to implementing EIA in Cameroon (Alemagi et al., 2007).

\subsection{Data Analysis}

Descriptive statistics (means and frequencies) were used to analyse the data and were computed using Microsoft Excel 2010. Mean responses were calculated for the 5-point interval scale questions, and proportions of respondents that had participated in forest-decision-making were reported. As this was an exploratory study, inferential statistics were not used.

\section{Results}

Results of this study are presented in six sections: (i) respondents' profiles; (ii) respondents' experiences with public participation in forest management decision-making; (iii) respondents' engagement in aspects of forest management decision-making; (iv) respondents' contributions to forest management decision-making; (v) respondents' levels of awareness of EIA legislation on public participation in forest management 
decision-making and their perceptions of the effectiveness of the implementation of this legislation; and, (vi) perceived hurdles to public participation processes. Each is discussed in turn.

\subsection{Respondents' Profiles}

A great deal of variety was observed in the 507 respondents. Most were residents of the communities under study, but had a variety of vocations, like hunting, farming, carpentry, hairdressing, hunting, care-giving, and so on (Figure 2).

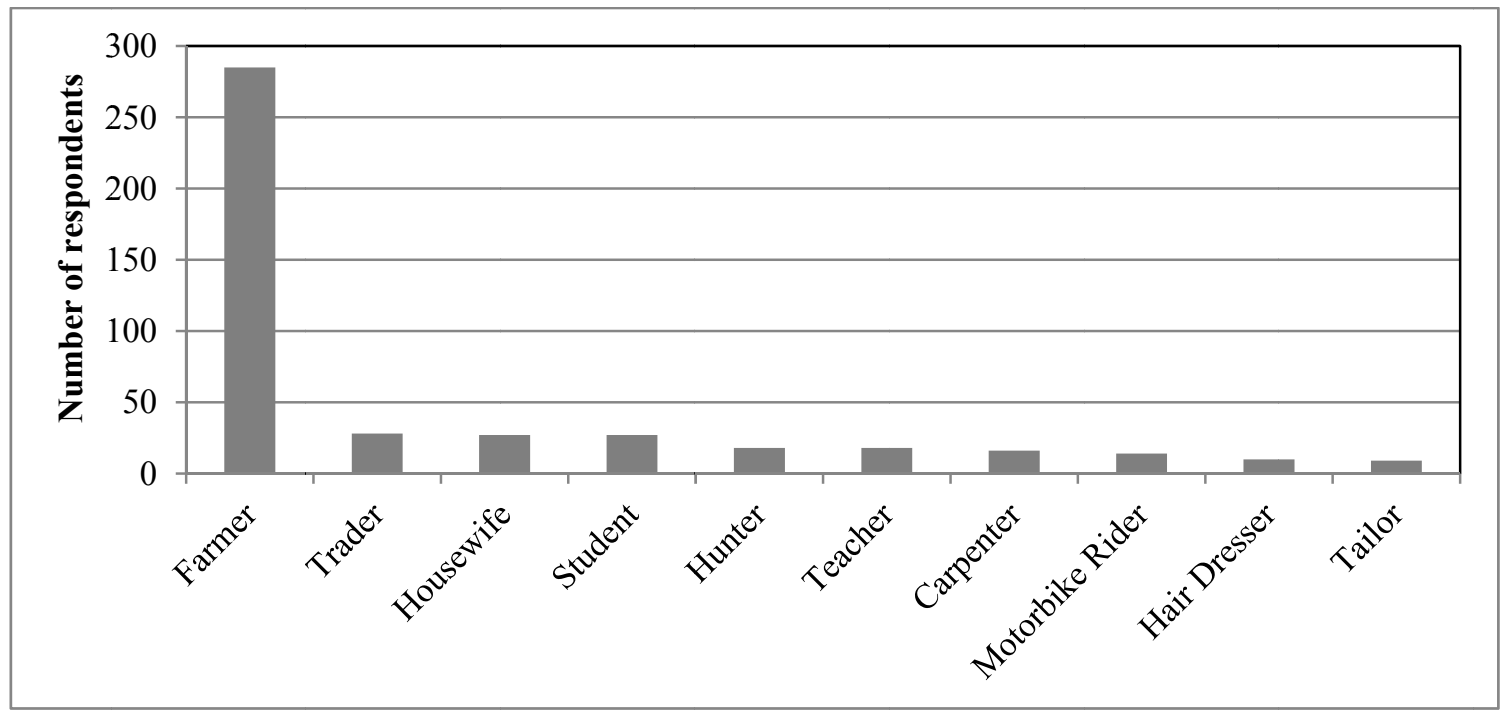

Figure 2. Number of respondents belonging to the top ten most predominant occupations in the case study communities

As seen in Figure 3, most interviewees were affiliated with one group or another, most with a religious group $(61 \%)$ or a community association $(48 \%)$, followed by a labour union $(10 \%)$. Some were employed by educational institutions $(6 \%)$, non-governmental organizations $(8 \%)$, or government $(3 \%)$. Almost 2 per cent of the sample self-identified as traditional leaders, and less than 1 per cent were employed by a forest-related corporation or an environmental consultancy.

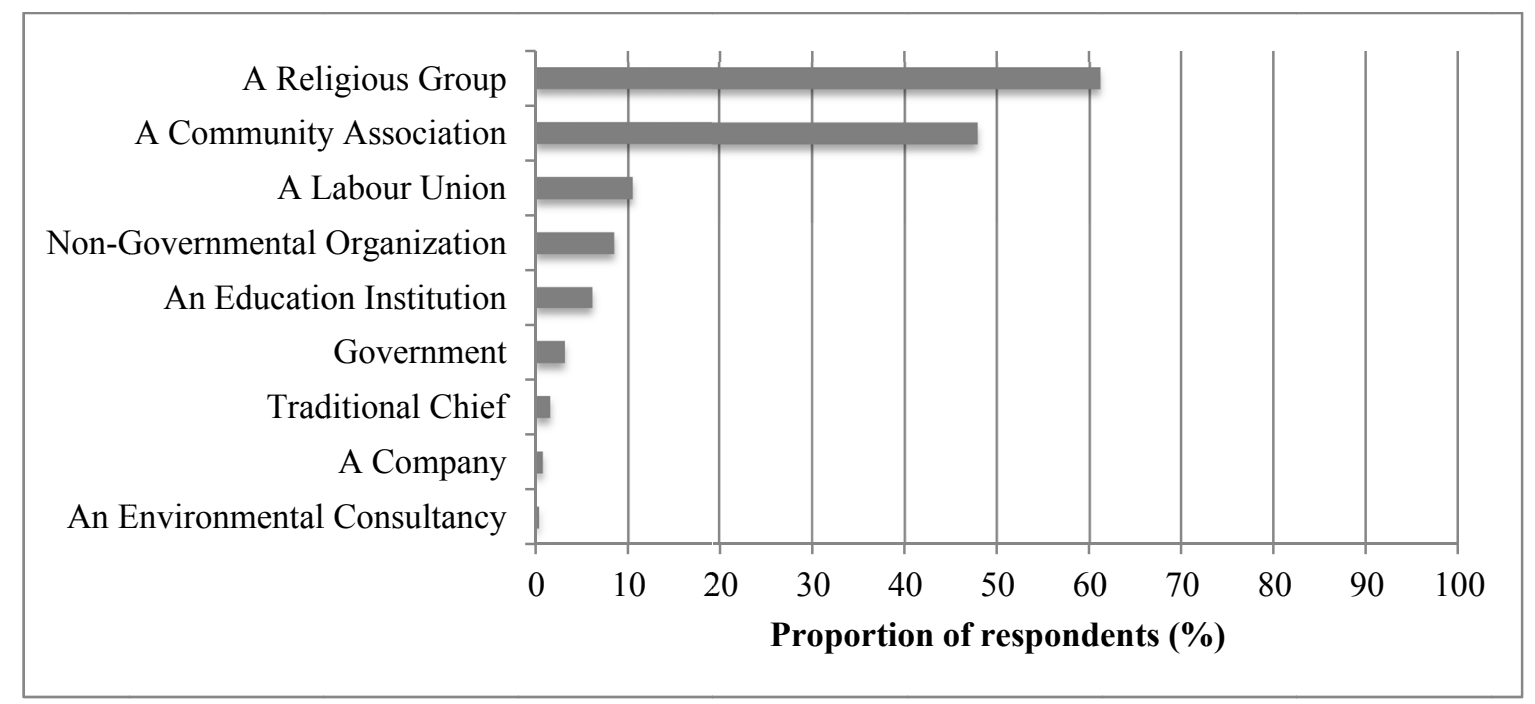

Figure 3. Proportions of respondents in the case study communities under each affiliation category.

Totals surpass $100 \%$ as respondents may have had more than one affiliation 


\subsection{Respondents' Experiences With Public Participation in Forest Management Decision-Making}

Of the 507 respondents that took part in the interviews, 61 per cent noted that they have never been involved in any forest management decision-making in their communities, while 39 per cent stated that they had. Of those who said they had been involved, 44 per cent indicated that they had taken part in decisions concerning timber exploitation by logging companies from forests within their communities, and the majority had taken part in related infrastructure development decisions.

The proportions of respondents who answered affirmatively to being involved in public consultations in each of the eight communities are seen in descending order in Figure 4. Notably, there is much variation in the results: the communities of Okoroba, Mbinda-Taboh, Ossing, and Bakogo seem to have had a much higher degree of involvement in forest management decision-making than the other communities.

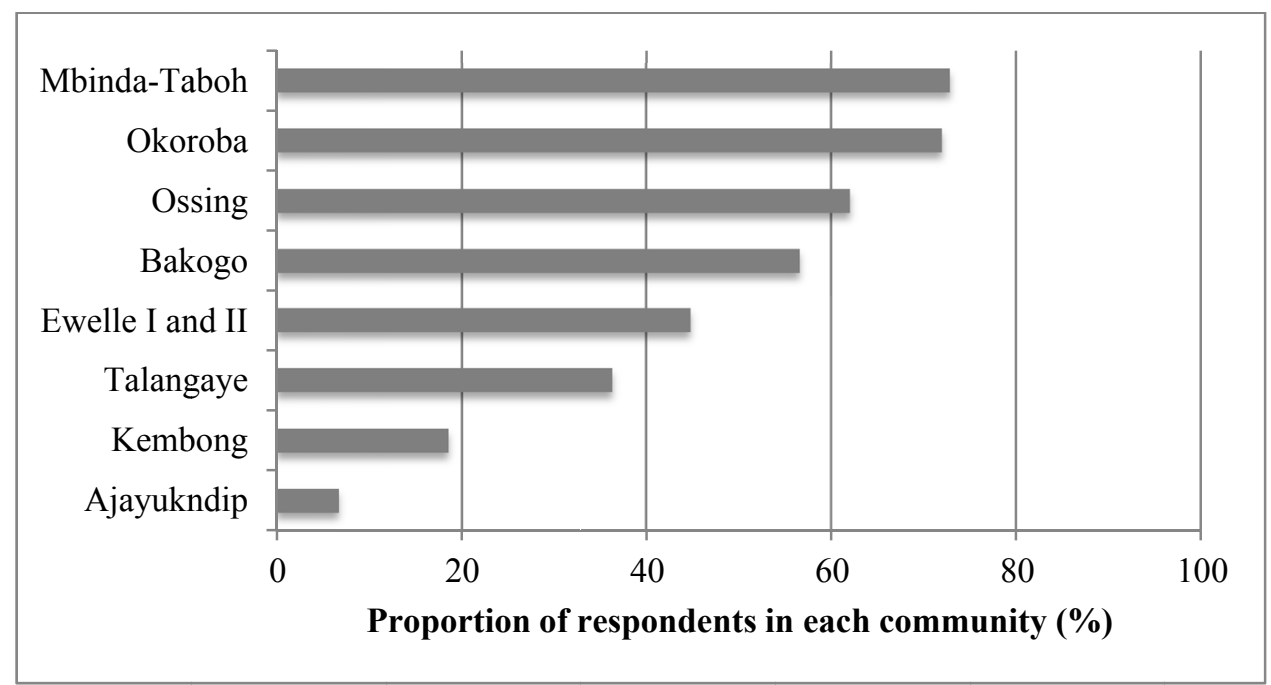

Figure 4. Proportions of respondents per community who have been involved in forest management decision-making processes

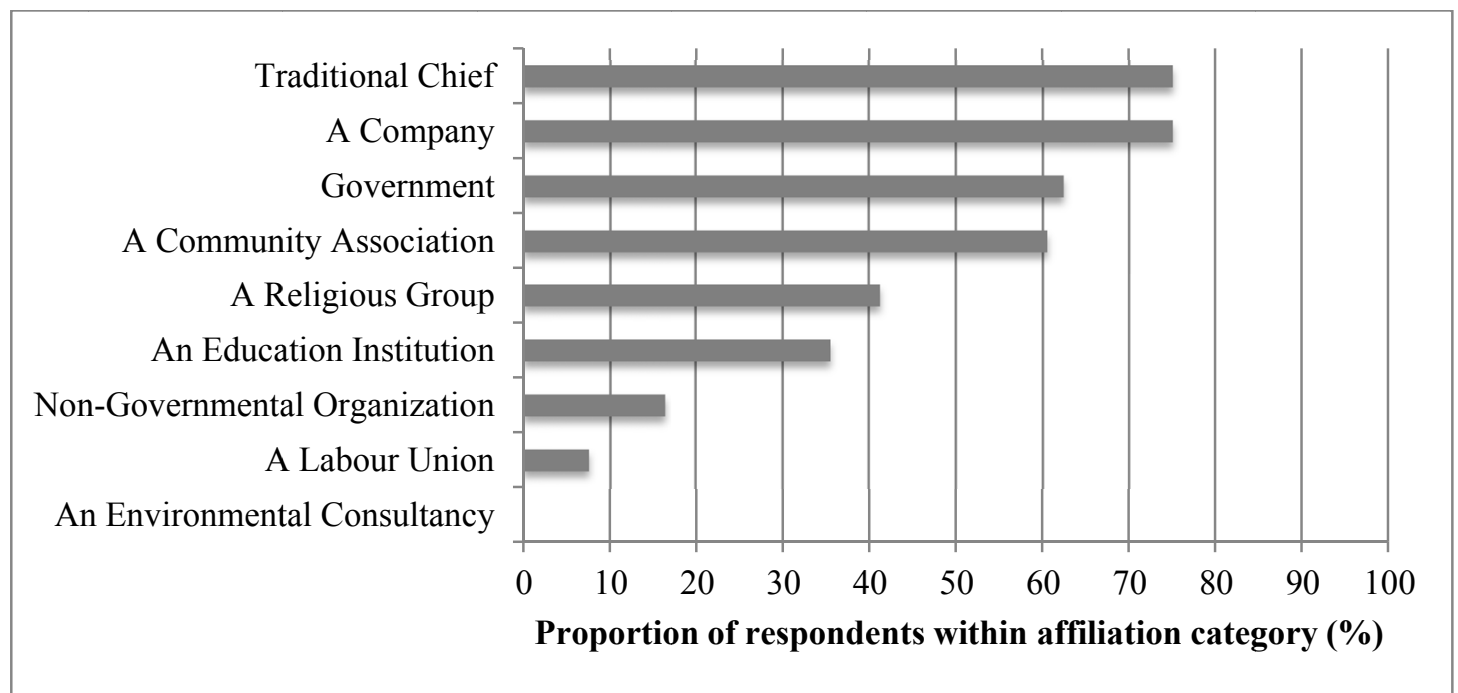

Figure 5. Proportions of respondents per affiliation category who have been involved in forest management decision-making processes

The proportions of respondents that have taken part in public forest-management decision-making processes are seen by affiliation in Figure 5. More than 70 per cent of participants affiliated with the traditional leadership or a company had participated in decision-making processes, while approximately 60 per cent of those affiliated with 
a community association or the government had. Approximately 40 per cent of those affiliated with a religious group or an education institution had participated in such a process, while smaller proportions (less than $20 \%$ ) of participants affiliated with the other groups had.

\subsection{Respondents' Engagement in Aspects of Forest Management Decision-Making}

Respondents who answered affirmatively about participation in forest management decision-making were asked to specify their engagement in various aspects of these consultation processes. The results, seen in Figure 6, show that supporting a project if environmental concerns are addressed and accepting the program of public participation (Note 8) were the two most frequently cited aspects at 135 and 93 counts, respectively. Interestingly, providing opposition to projects was the aspect of forest management decision-making least often reported by participants.

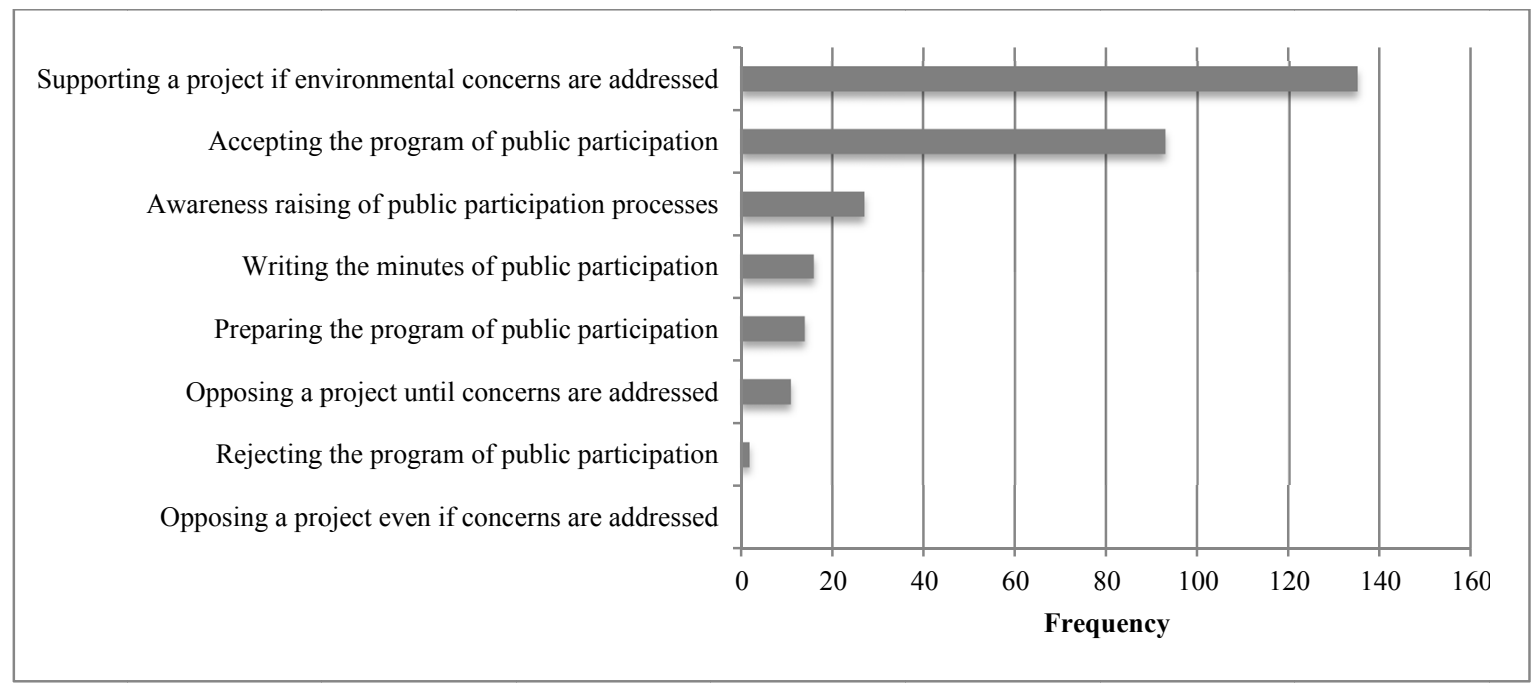

Figure 6. The 197 respondents that had participated in forest decision-making were asked to indicate what aspect of the forest management decision-making processes had they engaged in. This graph shows how many times each aspect was cited

\subsection{Respondents' Contributions to Forest Management Decision-Making}

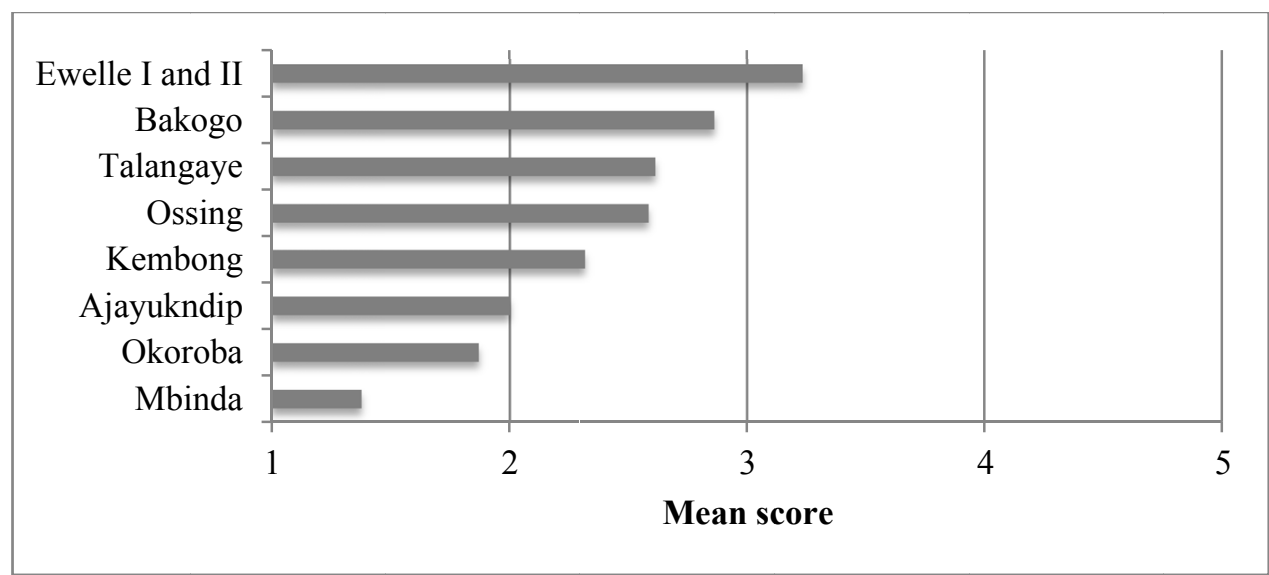

Figure 7. Perceived levels of contribution to forest management decision-making by community $(1=$ low; 5 high $)$

All respondents who were involved in forest management decision-making were asked to assess their levels of contribution to final decisions using a 5-point continuous scale ranging from $1=$ low to $5=h i g h$. The results, in the form of mean values, are summarized by community in Figure 7 and by affiliation in Figure 8. Again, there 
was a great variety in responses across communities, with all communities except Ewelle I and II and Bakogo scoring below 3 on 5 . In terms of affiliations, those working for a forest company scored their contribution to the final outcomes of the participation process as high (over 4), while all other affiliations scored their contribution close to or below 3, signifying lower levels of contribution to forest management decision-making processes.

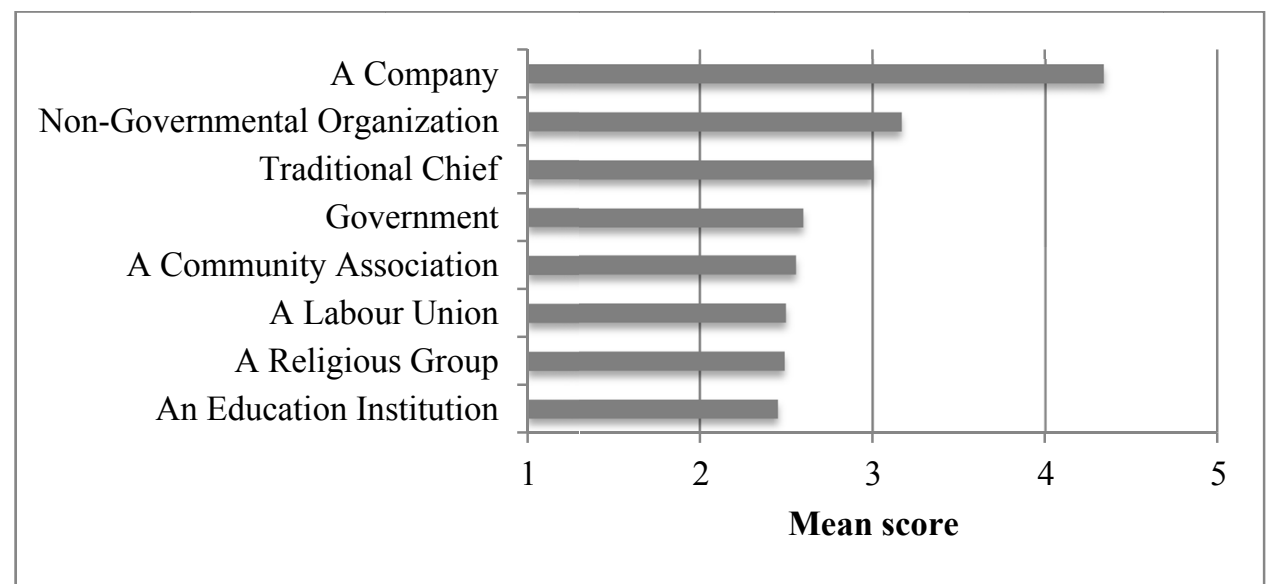

Figure 8. Perceived levels of contribution to forest management decision-making by affiliation $(1=$ low; $5=$ high). No representatives of the environmental consultancy group answered this question

\subsection{Respondents' Levels of Awareness of EIA Legislation on Public Participation in Forest Management Decision-Making and Perceptions of Effectiveness of Its Implementation}

In total, only 10 per cent of the respondents in all of the communities were aware of the Environmental Impact Assessment Decree (Decree N0. 2005/0577/PM) mandating public participation in any forest decision-making process in the country. While 22 per cent of participants in Bakogo had heard of the Decree, the level of awareness in other communities was very low or nil (Figure 9).

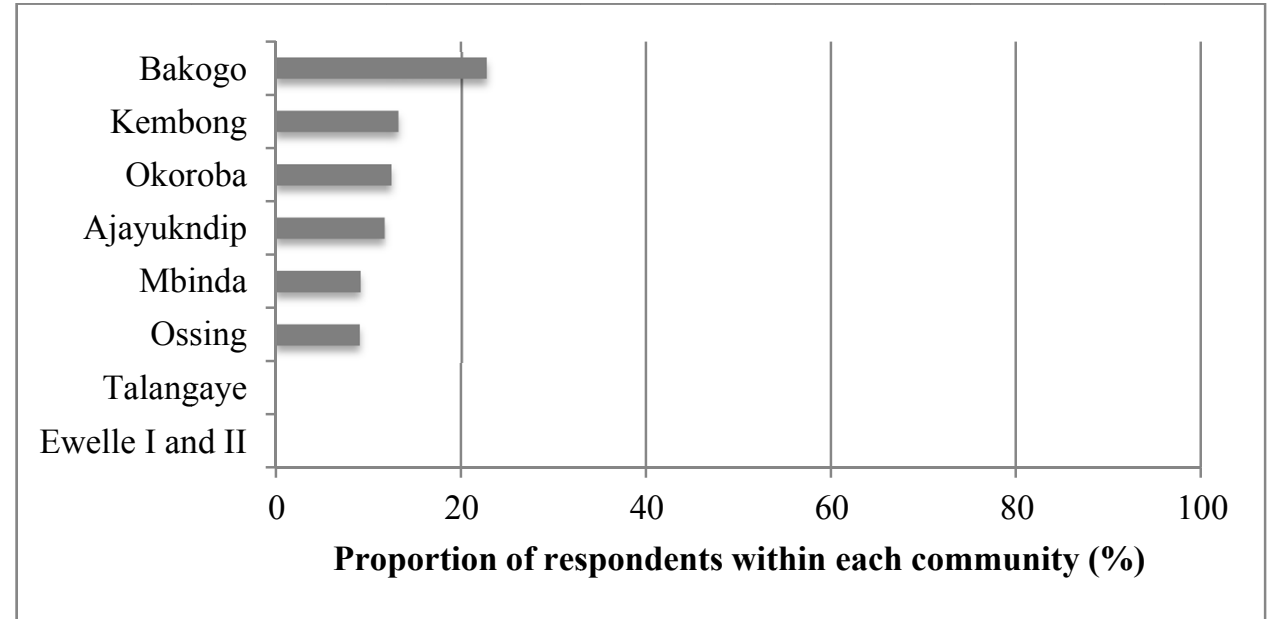

Figure 9. Proportion of respondents per community stating they were aware of the Environmental Impact Assessment Decree (Decree N0. 2005/0577/PM)

In terms of affiliation (Figure 10), the highest levels of awareness with respect to the EIA Decree (Decree N0. 2005/0577/PM) were observed amongst those with connections to a forest company (75\%), the government $(44 \%)$, or an educational institution (29\%). Labour unions, religious groups, NGOs, and community associations had the lowest levels of awareness. Surprisingly, those affiliated with an environmental consultancy had no awareness of the Decree; however, the small sample size of this group may have confounded this result. 


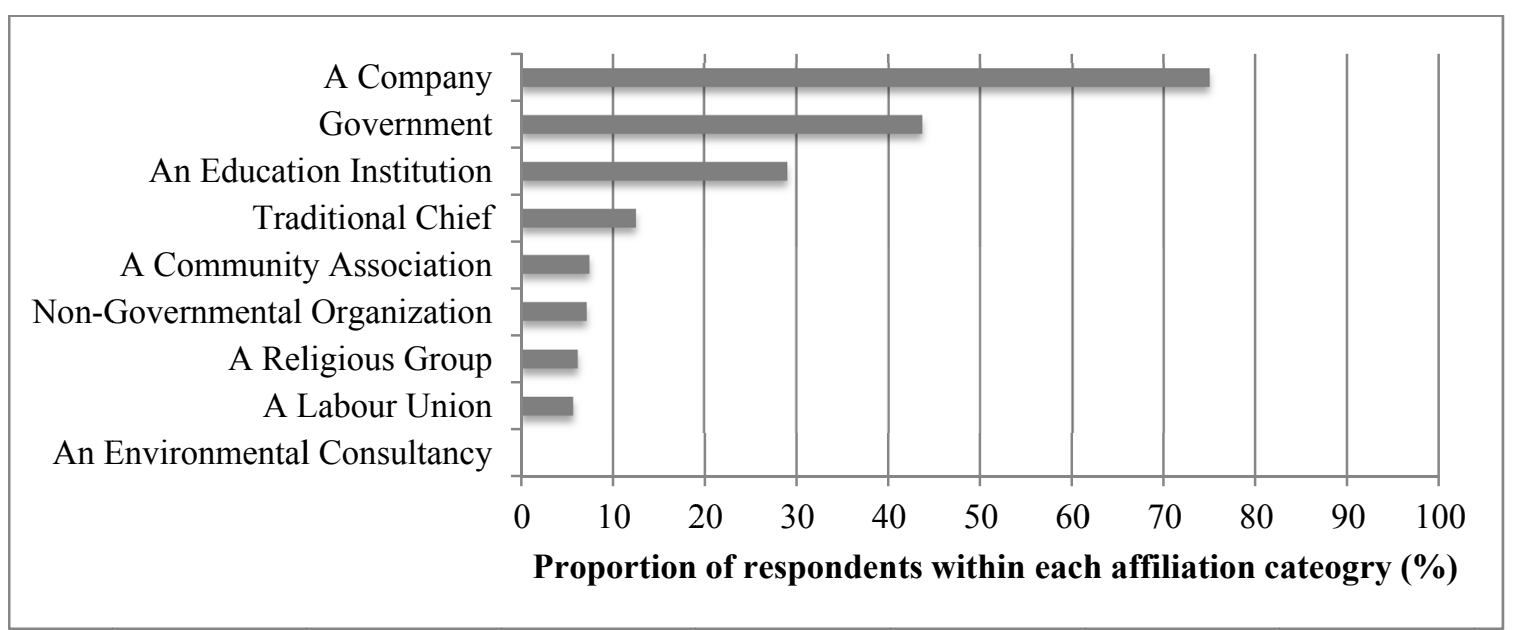

Figure 10. Proportion of respondents per affiliation category stating they were aware of the Environmental Impact Assessment Decree (Decree N0. 2005/0577/PM)

Respondents in each of the communities were also asked to rate the efficacy with which the government had promoted and implemented the EIA Decree using a 5-point continuous scale varying from $1=$ not at all effective to 5 = completely effective. Interestingly, Figure 11 shows that the mean scores in each of these communities tend to be less than 3 , indicating that all eight communities did not think highly of the efficacy of promotion and implementation efforts by the government. Overall, the small proportion of participants who had been aware of the EIA Decree had a slightly more favourable view of the government's implementation of it (average score of 2.4 compared to 1.9 for the whole sample).

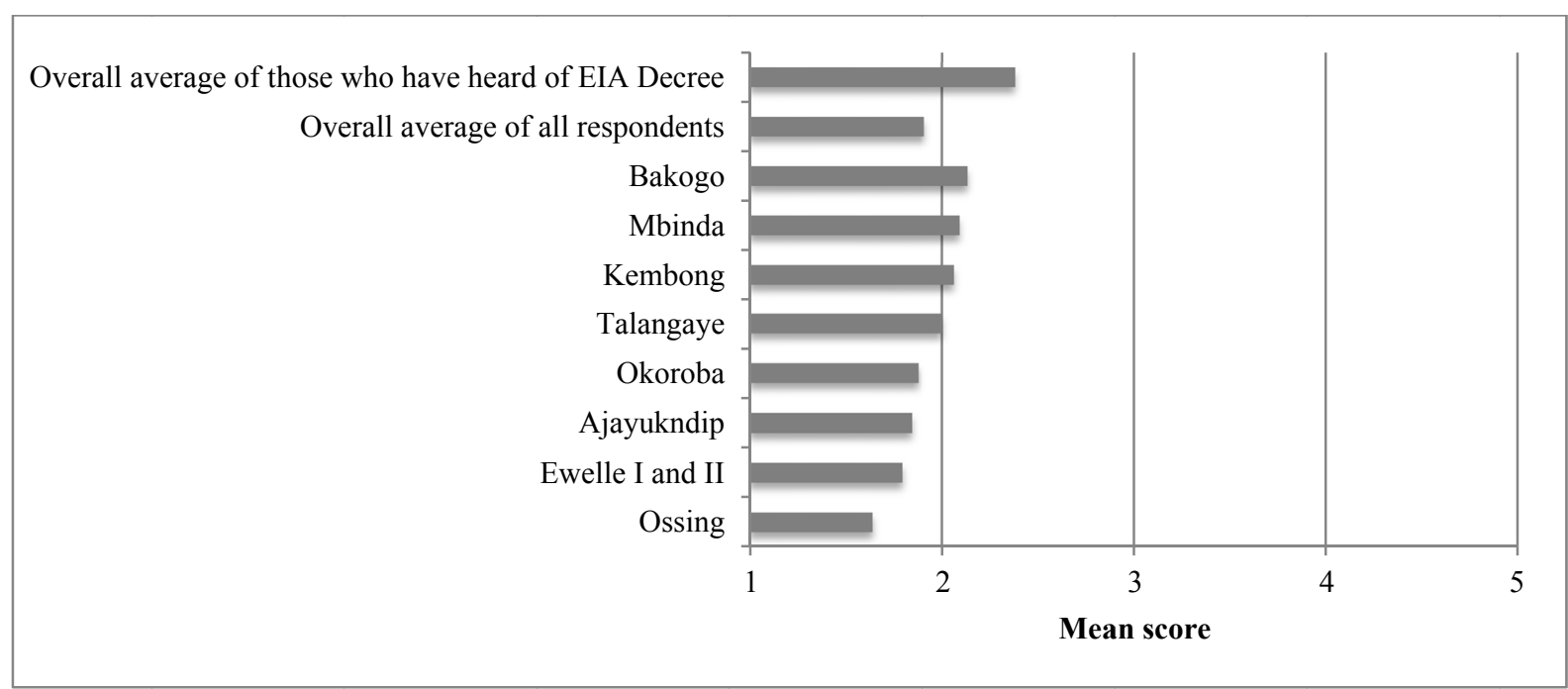

Figure 11. Respondents' perceptions towards the promotion and implementation of public participation by the government by community ( $1=$ not at all effective; $5=$ completely effective $)$

In terms of affiliation, all participants, apart from the forest company segment, perceived the promotion and implementation of this law by the government to be weak, with mean scores around 2 or lower (Figure 12). Interestingly, this suggests that even the sampled government employees do not think very highly of the efficacy of its promotion and implementation efforts. 


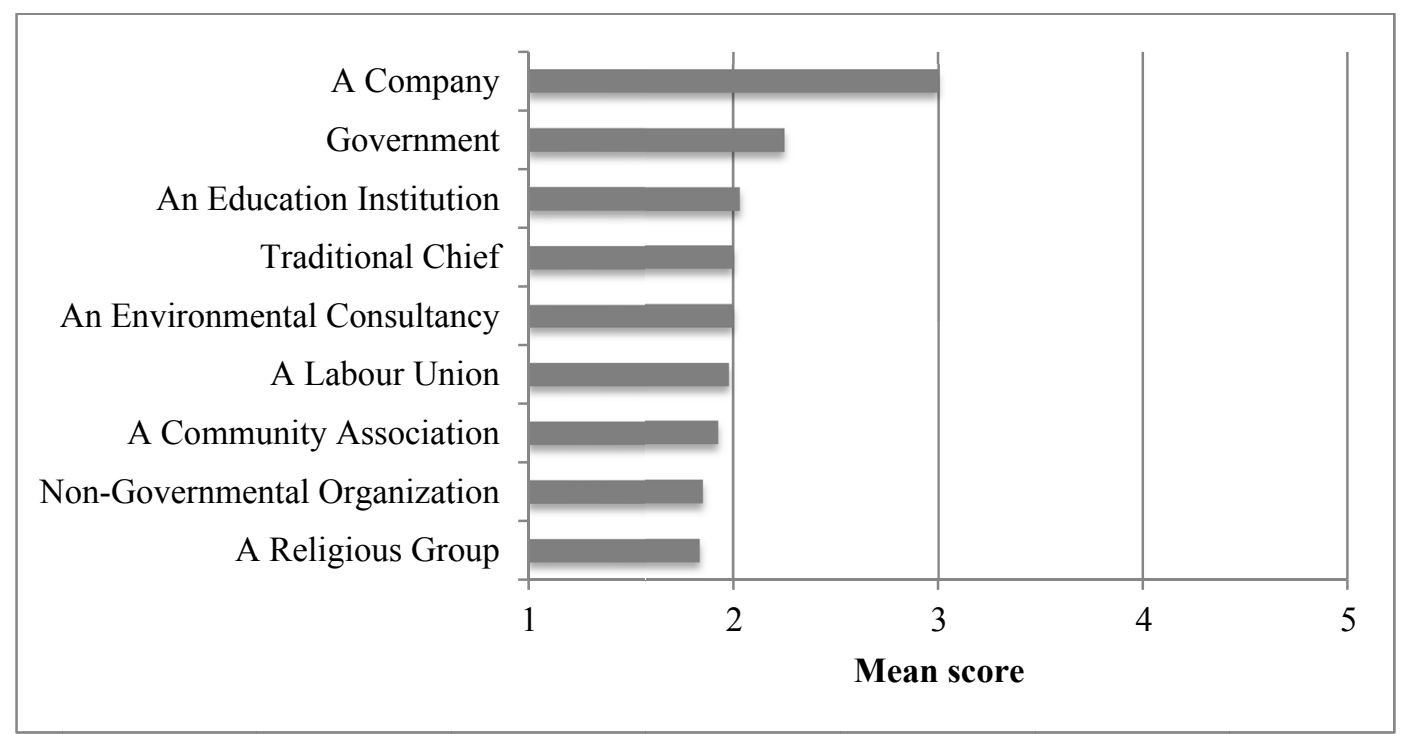

Figure 12. Respondents' perceptions towards the promotion and implementation of public participation by the government by affiliation ( $1=$ not at all effective; $5=$ completely effective $)$

\subsection{Perceived Hurdles to Public Participation Processes}

Community respondents were asked to rank a series of listed hurdles to effective public participation processes from 1 to 3 , with 1 being the most important hurdle. Differences in the way that respondents in each community ranked these hurdles are shown in Table 2. Inadequate education and awareness was ranked highly in almost all of the communities, with three-quarters or more of the respondents ranking this item first, second, or third. In most communities, except for Ossing and Mbinda-Taboh, a lack of competent administrative personnel was also often selected. Another significant hurdle was insufficient infrastructural resources, especially in the communities of Ajayukndip and Ossing.

Table 2. Rankings, in terms of proportions of respondents in each community ranking an item first, second, or third, of perceived hurdles affecting public participation by community (with the proportions of respondents ranking an item first in parentheses)

\begin{tabular}{|c|c|c|c|c|c|c|c|c|}
\hline & Okoroba & $\begin{array}{l}\text { Ewelle I } \\
\text { and II }\end{array}$ & Bakogo & Ajayukndip & Talangaye & Kembong & Ossing & Mbinda-Taboh \\
\hline $\begin{array}{l}\text { Inadequate education } \\
\text { and awareness }\end{array}$ & $\begin{array}{c}100 \\
(100)\end{array}$ & $93(58)$ & $64(51)$ & $88(69)$ & $97(78)$ & 77 (57) & $35(5)$ & $100(100)$ \\
\hline $\begin{array}{l}\text { Lack of government } \\
\text { enforcement }\end{array}$ & $3(0)$ & $6(0)$ & $19(0)$ & $12(3)$ & $3(0)$ & $44(8)$ & $6(3)$ & 0 \\
\hline $\begin{array}{l}\text { Poor planning and } \\
\text { organization }\end{array}$ & $91(0)$ & $4(0)$ & $26(0)$ & $18(7)$ & $27(0)$ & $23(6)$ & $\begin{array}{c}83 \\
(53)\end{array}$ & 0 \\
\hline High cost & 0 & $97(35)$ & $74(18)$ & $42(7)$ & $45(0)$ & $18(2)$ & $\begin{array}{c}68 \\
(11)\end{array}$ & $9(0)$ \\
\hline $\begin{array}{l}\text { Insufficient } \\
\text { infrastructure } \\
\text { resources }\end{array}$ & 0 & 0 & $30(8)$ & $73(10)$ & $39(5)$ & $46(7)$ & $\begin{array}{l}59 \\
(21)\end{array}$ & $18(0)$ \\
\hline $\begin{array}{l}\text { Lack of competent } \\
\text { administrative } \\
\text { personnel }\end{array}$ & $100(0)$ & $100(8)$ & 75 (24) & $58(3)$ & $82(16)$ & $75(20)$ & $45(7)$ & $36(0)$ \\
\hline
\end{tabular}

\section{Discussion}

The degree to which public participation in forest-dependent communities of Cameroon is actually taking place has been called into question by several previous studies. The present study reinforces this past work (see, for example, Bigombé Logo, 1994; Oyono et al., 2005; Oyono, 2005; Karsenty, 2007; Morrison, 2009; Foti \& Silva, 2010; Cerutti et al., 2010) in that results from a survey of eight forest-dependent communities in the Southwest 
Region of Cameroon show that the majority of respondents $(61 \%)$ have never taken part in an EIA-stipulated public process related to concession-based forest management. Those who have generally stated that their levels of participation and their perceived contributions to decision-making were low.

The experiences that respondents have had with participation in forest management decision-making vary by community, as well as the various aspects of the consultation process that they were engaged in within these communities. For example, the communities of Okoroba and Mbinda-Taboh were more involved in forest management decision-making than the other six communities surveyed. Two factors complicate this result and should be noted. First, concessionaires have operated for many years in Okoroba (see, for example, Steinhauer-Burkart, 1997; Valette, 2009), and many residents may already have had many consultations with the logging companies. Furthermore, there may be more of a vested interest in participating in consultation processes given that residents have witnessed years of forestry practices in the area. Similarly, in Mbida-Taboh, an EIA was conducted by one of the logging companies operating in the area in 2009 (see, CARFAD, 2009). However, in the case of Mbinda-Taboh, in particular, the community may not be seeing any benefits from forestry practices, and is greatly lacking social services such as good roads, electricity, and health care. It is also interesting to note that participants in Okoroba and Mbinda-Taboh had the lowest scores for their perceived level of contribution to final decisions in participatory forest management. In other words, although these community members had more often physically participated in decision-making processes, they were less likely to feel that they had contributed to the outcome, possibly because they have yet to see any tangible benefits as a result of forest management practices.

In terms of affiliation, those linked to the traditional leadership or a forest company stated that they have participated in forest management decisions more frequently than others. As Oyono (2005) reports, despite traditional claims largely being usurped by government in the form of publicly held lands, some community groups prefer to discuss forest management from a customary law point of view by recognizing the role of traditional chiefs as custodians of their local forests. In previous experiences in the region (Note 9), several community members had indicated that they felt such meetings and consultation processes were meant only for traditional councillors and chiefs, possibly explaining the higher participation of the traditional leadership versus other segments.

The observation of higher participation rates is not particularly surprising with respect to forest company affiliation. As De Blass and Pérez (2008) note, forest companies in Cameroon are becoming increasingly concerned about environmental issues. Thus, respondents who worked in these forest products firms likely have a higher degree of knowledge and awareness with respect to forest management, resulting in higher levels of involvement in consultation processes. It is interesting, however, that most of these company affiliates are brought in from outside of the community by the forest companies. In other words, those who feel that they are participating most frequently in forest management decision-making are not even long-term residents of the communities.

The two most frequently cited aspects of the consultation process that respondents engaged in included: (1) supporting a project if environmental concerns are addressed and (2) accepting the programs of public participation, the latter being a fairly innocuous procedural document usually accepted by the public with little dissent. Interestingly, opposition to projects was the least frequently cited aspect of the consultation process that respondents were engaged in during public forest management decision-making processes. Although not tested in this study, past work on public protests against resource projects in Cameroon (Jobin, 2003; Utzinger, et al., 2005; Alemagi, 2007) offers one possible explanation for this result. Intimidation tactics and human rights violations have been known to occur during public consultations for natural resource exploitation in Cameroon and the public may be fearful of reprisal. For example, in Okoroba, respondents reported that peaceful protests against a timber exploitation project in 2008 resulted in the arrest and detention of protesters. Others have further illustrated this point by documenting that armed security forces were present during public consultation of affected groups in the planning phase of the Chad-Cameroon petroleum and pipeline project (Jobin, 2003; Utzinger et al., 2005, Alemagi, 2007).

Most of the respondents had generally negative perceptions towards the promotion and implementation of public participation programs in forest-based concessions by the government (with mean scores of less than 3 on a 5-point scale). Forest company affiliates had the most positive perceptions, but interestingly, participating government employees seemingly did not think very highly of the government's efforts to promote and implement these programs. The low scores across the board may be a reflection of the fact that there is a widespread perception of corruption and distrust of the government's ability to hold forest companies and other public institutions accountable for meeting their social obligations such as ensuring that adequate public 
participation takes place (Bigombé Logo, 1994; Oyono, 2004; Oyono et al., 2005; Oyono, 2005; Morrison, 2009; Foyi \& Silva, 2010). This is reinforced in this study by the finding that a lack of competent administrative personnel was ranked very highly by interviewees in terms of perceived hurdles to effective participation. Another possible reason underpinning the poor implementation of the Decree may relate to political jostling and posturing on the part of newly formed Cameroonian ministries. The adoption of the decree in 2005 came less than a year after the separation of the then Ministry of Forests and Environment into the current Ministries of Forests and Wildlife (MINFOF) and Environment, Nature Protection and Sustainable Development (MINEPDED). Arguably, MINEPDED's focus on environmental protection may be at odds with forest concessionaires operating in the region, consequently obstructing the seamless implementation of the Decree in some cases.

The issue of insufficient infrastructural resources was ranked highly in Ajayukndip and Ossing. Neither community had adequate infrastructural resources (like town halls) for effective and efficient planning to take place. On another note, inadequate education and awareness is perceived as the most important hurdle limiting public participation in forest management decision-making, a trend that was observed in each of the surveyed communities. As Alemagi et al. (2007) explain, illiteracy in English and French remains a setback to effective and efficient public participation in Cameroon. The fact that most official documents in Cameroon are only published in French (and, at times, in English and French) is a major impediment to effective public participation by the illiterate populace. The findings here show that the communities of Kembong and Bakogo, as well as respondents affiliated with forest corporations, the government, and education institutions, had higher levels of awareness of legislation regarding public participation in forest management decision-making. As above, one possible explanation may relate to literacy. In these cases, though, the presence of many literate professionals (teachers, students, and councillors, nurses, civil servants, and so forth) with a mastery of English and/or French means that they should be able to help explain official forestry documentation to those community members who cannot read. The connection between low levels of education and awareness and public participation in environmental management decision-making has been observed previously in a similar community in neighboring Nigeria, with Adomokai and Sheate (2004) stating that there is a need for all stakeholders to be properly educated as a fundamental prerequisite for effective public participation.

\section{Concluding Remarks and a Path Forward}

This paper highlights the degree to which the public in eight forest-dependent communities of the Southwest Region of Cameroon are engaged in forest management decision-making under a concession-based forestry model, as prescribed by the Environmental Impact Assessment (EIA) Decree (No. 2005/0577/PM). In addition, it also outlines local perceptions of the role of the government in promoting public participation in these communities, and identifies challenges affecting successful public participation.

The results indicate that 61 per cent of community respondents have never taken part in a formal forestry decision-making process. Additionally, those who have participated generally stated that their contributions were minimal. The results also indicate generally negative perceptions by the communities towards the promotion and implementation of public participation programs by the government. It is the government's responsibility to ensure that public participation provisions contained in EIA legislation are implemented. Thus, it can be expected that those who do not feel that they have adequately participated in the decision-making process, or do not acknowledge many benefits coming from forest companies' activities, will place the blame, at least in part, on insufficient forest governance. Thus, these results point to a pressing need for the government to be more proactive in ensuring that their obligations to a participatory process, as stipulated by the EIA Decree, are fulfilled. However, we acknowledge that this study only focuses on the narrow scope of the EIA participation process, which is just one part of the arsenal of legislative tools prescribing the social and environmental obligations of forestry companies. Additional obligations prescribed in their cahiers des charges and forest management plans also need to be fulfilled for the benefit of the communities in which they are located. This could be achieved by the appointment of competent administrative personnel, as well as promoting the importance of accountability, transparency, and rigour in the enforcement of responsible corporate practices. It is also important to note that other, non-legislative tools, namely forest certification, do exist and are increasingly being adopted in the region, which may serve to enhance public participation in concession-based forestry (Lescuyer et al., 2012).

Finally, this study also reveals that respondents perceive that inadequate education and awareness are the most significant hurdles affecting public participation in forest management decision-making. There is a salient need to address this issue, and it is recommended that greater consideration be given to community empowerment through the translation of official forestry documents into local languages, as well as to the use of radio and/or 
television to communicate major aspects of these documents to the illiterate population. However, there is also a need to implement, in such situations, consultation and participation strategies that take into account linguistic differences and literacy levels, such as those developed for free, prior and informed consent processes elsewhere (Lewis, 2012).

Oftentimes, it seems that public participation is limited to members of the traditional council. In order to achieve more balanced and inclusive participation, key stakeholders driving the process (governments and forest products companies) should make a concerted effort to ensure that the knowledge, experiences, and opinions of the majority of community members are represented in public participation processes related to forest management decision-making.

\section{Acknowledgements}

We would like to thank all of the participants in the eight forest communities for their hospitality and for giving us their valuable time to participate in these interviews. We would also like to thank the two research assistants, Mboh Tanyi Mbo and Njong Gideon, involved in the data collection, as well as Nkeumoe Frederick Numbisi for help with data entry. This research was funded by a grant from the Social Sciences and Humanities Research Council of Canada and the CGIAR Research Program (CRP) 6.1 and 6.3.

\section{References}

Adomokai, R., \& Sheate, R. T. (2004). Community participation and environmental decision-making in the Niger Delta. Environmental Impact Assessment Review, 24(5), 495-518. http://dx.doi:10.1016/j.eiar.2004.01.002

Alemagi, D. (2007). The oil industry along the Atlantic Coast of Cameroon: Assessing impacts and possible solutions. Resources Policy, 32(3), 135-145. http://dx.doi:10.1016/j.resourpol.2007.08.007

Alemagi, D., \& Kozak, R. A. (2010). Illegal logging in Cameroon: Causes and the path forward. Forest Policy and Economics, 12(8), 554-561. http://dx.doi:10.1016/j.forpol.2010.07.008

Alemagi, D., Sondo, A. V., \& Ertel, J. (2007). Constraints to environmental impact assessment practice: A case study of Cameroon. Journal of Environmental Assessment Policy and Management, 9(3), 357-380. http://dx.doi: 10.1142/S1464333207002809

Ammenberg, J. (2003). Do standardised environmental management systems lead to reduce environmental impacts? Doctoral thesis. Linkoping University: Institute of Technology.

Assembe Mvondo, S., \& Sangkwa, F. (2009). Council forests: The case of Dimako. In M. C. Diaw, T. R. Aseh, \& Prabhu (Eds.), In Search of Common Ground: Adaptive Collaborative Management in Cameroon (pp. 95-116). Bogor, Indonesia, Center for International Forestry Research (CIFOR).

Bigombé Logo, P. (1994). A qui profite l'exploitation forestière à l'Est-Cameroun? LaVoix du Paysan, 33, 9-10.

Bitondo, D. (2000). Environmental assessment in Cameroon: state of the art. Impact Assessment and Project Appraisal, 18(10), 33-42. http://dx.doi: 10.3152/147154600781767592

Bombay, H. (1996). Aboriginal forest-based ecological knowledge in Canada. Discussion paper. Ottawa: National Aboriginal Forestry Association.

Brown, H., \& Lassoie, J. (2010). Institutional choice and local legitimacy in community-based forest management: lessons from Cameroon. Environmental Conservation, 37(3), 261-269. http://dx.doi.org/10.1017/S0376892910000603

Buchy, M., \& Hoverman, S. (2000). Understanding public participation in forest planning: a review. Forest policy and Economics, 1, 15-25. http://dx.doi.org/10.1016/S1389-9341(00)00006-X

CARFAD. (2009). Environmental impact assessment for the forest management unit N. 11 005. Eyumojock Sub-Division, Manyu Division, Southwest Region, Cameroon. Yaoundé: African Centre for Applied Forestry Research and Development.

Cerutti, P. O., Lescuyer, G., Assembe-Mvondo, S., \& Tacconi, L. (2010). The challenges of redistributing forest-related monetary benefits to local governments: a decade of logging area fees in Cameroon. International Forestry Review, 12(2), 130-138. http://dx.doi.org/10.1505/ifor.12.2.130

CIFOR. (2006). Equal partners: saving forests and improving livelihoods. CIFOR Newsletter N0. 41. Bogor: Center for International Forestry Research.

Coskun, A. A., \& Elvan, D. O. (2003). Urgent Amendments on Turkish Forest Legislation Concerning 
Participation. Quebec City: XII World Forestry Congress. Retrieved from http://www.fao.org/DOCREP/ARTICLE/WFC/XII/0159-A4.HTM

De Blas, D. E., \& Perez, M. R. (2008). Prospects of reduced impact logging in Central African logging concessions. Forest ecology and management, 256(7), http://dx.doi:10.1016/j.foreco.2008.05.016

De Blas, D. E., Ruiz-Pérez, M., \& Vermeulen, C. (2011). Management conflicts in Cameroonian community forests. Ecology and Society, 16(1), 8.

Diaw, M. C., Prabhu, R., \& Aseh, T. (2009). Assembling the ACM mosaic: Reflections and conclusions. In M. C. Diaw, R. Prabhu, \& T. Aseh (Eds.), In search of common grounds: adaptive collaborative management in Cameroon (pp. 443-475).

Duinker, P. (1998). Public participation's promising progress: advances in forest decision-making in Canada. Commonwealth Forestry Review, 77(2), 107-112. http://dx.doi:10.1080/00049158.1977.10674156

Foti, J., \& Silva, L. D. (2010). A seat at the table: Including the poor in decisions for development and environment. Washington, DC: World Resources Institute.

Friends of the Earth International. (2005). Nature: Poor people's wealth. The importance of natural resources in poverty eradication. Amsterdam: Friends of the Earth International. Retrieved from http://www.foei.org/publications/pdfs/poverty.pdf

Global Witness. (2010). Cameroon Indicators - Fiscal regime: tax collection and redistribution 2010. Annual Transparency Report. Retrieved from: http://www.foresttransparency.info/cameroon/2010/themes/12/65/

Israel, G. D. (2012). Sampling issues: nonresponse. University of Florida: PEOD9 Series, Agricultural Education and Communication Department.

Jobin, W. (2003). Health and equity impacts of a large oil project in Africa. Bulletin of the World Health Organization, 81, 420-426.

Jum, C., Diaw, M. C., Nguiebouri, J., \& Zoa, M. (2007). Enhancing sustainable forest management in Cameroon through the model forest approach in Cameroon. International Forestry Review, 9(4), 892-900. http://dx.doi.org/10.1505/ifor.9.4.892

Jum, C., \& Oyono, P. R. (2005). Building collaboration through action research: the case of Ottotomo forest reserve in Cameroon. International Forestry Review, 7(1), 37-43. http://dx.doi.org/10.1505/ifor.7.1.37.64160

Karsenty, A. (2007). Overview of industrial forest concessions and concession-based industry in Central and West Africa and considerations of alternatives. Washington DC: Rights and Resources Initiative Group,

Karsenty, A, Jegou, C., \& Singer, B. (2008). Social policies of forest concessionaires in West and Central Africa. Paris: CIRAD.

Kongape, J. A., \& Etoa-Akoa, L. P. A. (2011). La foresterie sociale au Cameroun: Leçons apprises et perspectives. Yaoundé: Ministère des Forets et de la Faune.

Kozak, R. A., Stetic, W. C., Harshaw, H. W., Maness, T. C., \& Sheppard, S. R. J. (2008). Public priorities for sustainable forest management in six forest-dependent communities of British Columbia. Canadian Journal of Forest Research, 38(12), 3071-3084. http://dx.doi:10.1139/X08-146

Kvale, S. (1996). Interviews. Thousand Oaks, CA: SAGE.

Lescuyer, G., Assembe Mvondo, S., Essoungou, J. N., Toison, V., Trébuchon, J. F., \& Fauvet, N. (2012). Logging Concessions and Local Livelihoods in Cameroon: from Indifference to Alliance? Ecology and Society, 17(1), 7. http://dx.doi.org/10.5751/ES-04507-170107

Lewis, J. (2012). How to implement free, prior informed consent. Participatory Learning and Action, 65, $175-178$.

Mendoza, G., \& Prabhu, R. (2000). Multiple criteria decision making approaches to assessing forest sustainability using criteria and indicators: a case study. Forest Ecology and Management, 131, $107-126$. http://dx.doi.org/10.1016/S0378-1127(99)00204-2

MINEF. (1994). A compendium of official instruments on forest and wildlife management in Cameroon. Yaoundé: Ministry of Environment and Forests. 
MINFOF. (2009). Manual of the Procedures for the attribution, and norms for the management of Community Forests in Cameroon. Yaoundé: Ministry of Environment and Forests.

Montreal Process Working Group. (1999). The Montreal process: criteria and indicators for the conservation and sustainable management of temperate ad boreal forests (2nd ed.). Ottawa: Montreal Process Liaison Office.

Morrison, K. (2009). Broken promises: Forest revenue-sharing in Cameroon. WRI Forest Note. Washington, DC: World Resources Institute.

Nchotaji, N. M. (2010). Participatory forest resource governance: The Mount Cameroon Experience. Paper presented at the 2010 Berlin Conference on the Human Dimensions of Global Environmental Change: Social dimensions of environmental change and governance 8-9 October 2010.

Njoh, A. J. (2007). Politico-economic determinants of forestry policy in Cameroon. Geo-Journal, 70, 109-120. http://dx.doi 10.1007/s10708-008-9118-z

Nguemdjom, A. (2006). Dilemmas in tackling deforestation in Cameroon. One world Cameroon guide. Retrieved from http://uk.oneworld.net/article/view/142737/1/

Nguene, F. R., Fonocho, C., Enjoh, J., Taza-Asaba, L., \& Nien Ngapout, S. A., (2012). Role and Level of Stakeholders Involvement in the EIA Practice in Cameroon: Case of EIAs of the Upstream Energy Sector. Retrieved from www.iaia.org

Nguinguiri, J. (1999). Les approches participatives dans la gestion des écosystèmes forestière d'Afrique Centrale. Occasional Paper No. 23. Bogor: Centre for International Forestry Research.

OFAC. (2012). Données économiques du secteur forestier, statistiques forestières et transformation du bois au Cameroun. Observatoir des forets d'Afrique Centrale.

Ojha, H., Laurent, P., \& Ashwini C. (2009). Community Forestry in Nepal: A policy innovation for local livelihoods. IFPRI Discussion Paper 00913.

Oxford Dictionaries Online. (2013). Definition of perception in English. Retrieved from http://oxforddictionaries.com/definition/english/perception

Oyono, P. R. (2004). One step forward, two steps back? Paradoxes of natural resource management decentralization in Cameroon. Journal of Modern African Studies, 42(1), 91-111. http://dx.doi.org/10.1017/S0022278X03004488

Oyono, P. R. (2005). Profiling local-level outcomes of environmental decentralizations: The case of Cameroon's forests in the Congo Basin. The Journal of Environment and Development, 14(3), 317-337. http://dx.doi: $10.1177 / 1070496505276552$

Oyono, P. R., Kouna, C., \& Mala, W. (2005). Benefits of forests in Cameroon. Global structure, issues involving access and decision-making hiccoughs. Forest Policy and Economics, 7(3), 357-368. http://dx.doi:10.1016/S1389-9341(03)00072-8

Pretty, J., \& Smith, D. (2004). Social Capital in Biodiversity Conservation and Management. Conservation Biology, 18(3), 631-638. http://dx.doi: 10.1111/j.1523-1739.2004.00126.x

Rainforest Foundation \& Forest Monitor. (2007). Concessions to Poverty: The environmental, social and economic impacts of industrial logging concessions in Africa's rainforests. Washington DC: Rights and Resources Initiative Group.

RoC. (1994). 1994 Law No 94/01 of 20 January 1994 establishing forestry, wildlife and fisheries regulations. Yaoundé: Presidency of the Republic,

Shindler, B., \& Neburka, J. (1997). Public participation in forest planning: eight attributes of success. Journal of forestry, 95(1), 17-19.

Sinclair, A. J., \& Doelle, M. (2003). Using law as a tool to ensure meaningful public participation in environmental assessment. Journal of environmental law and practice, 12, 27-54.

Steinhauer-Burkart, B. (1997). Environmental impact assessment (EIA) in the timber concession MPL and CAFECO within Korup Project Area. Eschborn: Deutsche Gesellschaft Fuer Technische Zusammenarbeit (GTZ).

UN Food and Agriculture Organization. (2012). Website on Participatory Forestry. Retrieved from http://www.fao.org/forestry/participatory/en/ 
United Nations Commission on Sustainable Development (UNCSD). (1992). Non-legality binding authoritative statement of principles for a global consensus on the management, conservation and sustainable development of all types of forests. Annex III to the Report of the United Nations Conference on the Environment.

Utzinger, T., Wyss, K., Moto, D. D., Yemadji, N., Tanner, M., \& Singer, B. H. (2005). Assessing health impacts of the Chad-Cameroon petroleum development and pipeline project: challenges and a way forward. Environmental impact assessment review, 25, 63-93. http://dx. doi.org/10.1016/j.eiar.2004.04.002

Valette, A. (2009). Certification de gestion forestière FSC. Rapport résume public de certification, enterprise TRC-UFA 00-004. Paris: Bureau Veritas Certification.

World Bank. (2011). Time for the Lion to wake up? An economic update on Cameroon with a special focus on Telecoms. Cameroon Economic Update. Issue No. 1. Yaoundé: Poverty Reduction and Economic Management Unit of the World Bank.

World Commission on Forest and Sustainable Development (WCFSD). (1999). Our forest, our future: Report of the World Commission on Forest and Sustainable Development. Cambridge: Cambridge University Press.

\section{Notes}

Note 1. 18.9 billion CFA Franc is approximately 37 million USD (as of April 2013).

Note 2. Karsenty et al. (2008) touched on participatory mapping as stipulated by the EIA in their review of social policies of forest concessionaires in West and Central Africa.

Note 3. Perception is "the way in which something is regarded, understood, or interpreted" (Oxford Dictionaries Online, 2013). Thus, perception in this study was used to measure if and how people believed they have or are participating, and their understanding or interpretation of participation.

Note 4. This community is given two names because a stream separates Ewelle I and Ewelle II.

Note 5. An appeal (through traditional leaders) was made to a diverse group of people in each community and those interested were recruited for interviews. Appointments for interviews were also arranged by traditional leaders.

Note 6. A random household sample was not possible because many of the people in the communities are farmers who are rarely at home.

Note 7. These employees are mostly Cameroonian nationals who lived in the communities, but had been brought in by the forest companies operating in the area.

Note 8 . The EIA Decree requires a notice of the meeting to be circulated to representatives of the affected populations 30 days prior to the first meeting, in addition to the programme of consultations (dates and venues) and written reports of the project being assessed. The programme / agenda is "accepted" at the start of the meetings by those in attendance.

Note 9. By the lead author of this present study.

\section{Copyrights}

Copyright for this article is retained by the author(s), with first publication rights granted to the journal.

This is an open-access article distributed under the terms and conditions of the Creative Commons Attribution license (http://creativecommons.org/licenses/by/3.0/). 